\title{
Teologie a sociální práce ve Španělsku - přehled, zkušenosti a koncepce v magisterském studijním programu Sociální rozvoj na Katolické univerzitě San Antonio v Murcii \\ Rainer Gehrig
}

\begin{abstract}
Abstrakt
Předložený článek popisuje situaci ohledně nabídek studijních možností pro Sociální práci a Sociální pedagogiku ve Španělsku na soukromých katolických univerzitách a ohledně integrace teologických obsahů studia do kurikul. Ve druhé části jde o specifickou situaci a zkušenosti s integrací teologie na Katolické univerzitě San Antonio v Murcii (Španělsko), a to zejména v kombinovaném magisterském studijním programu „Sociální rozvoj”.
\end{abstract}

Klíčová slova: sociální práce, sociální pedagogika, teologie, sociální rozvoj, kurikula

\section{Sociální práce ve Španělsku}

Vývoj moderní sociální práce ve Španělsku lze - viděno z historického hlediska - zkoumat ve spojitosti s rozvojem vzdělávacích zařízení a jejich programů. ${ }^{1}$ Tato institucionalizace počínající zrrízením první školy v Barceloně v roce 1932 na počátku druhé republiky a před vypuknutím Španělské občanské války (1936-1939) ukazuje vývoj sociální práce ve Španělsku v obdobích založení, Frankovy diktatury, konsolidace škol v 60. letech a integrace do univerzitního vzdělávání v roce 1983 coby prozatímního konce institucionalizace profese. V předpolí těchto škol stojí vedle široce rozvětvené, relativně nekoordinované oblasti charitativních organizací také reformní iniciativy španělského „sociálního katolicismu“ ${ }^{\text {“2 }}$ jeho katolickými kroužky dělníků, odbory a fóry reflektujícími situaci, jako jsou „Španělské sociální týdny“, 3 pro nějž byla významným podnětem první sociální encyklika Rerum novarum papeže Lva XIII (1891). Vliv katolické církve ve Španělsku v 50. a 60. letech 20. století, zejména také díky organizaci Caritas Española založené v roce 1947, vedl k rozvoji církevních vzdělávacích center (15 zařízení jen v roce 1958 a 30 celkem) a ke koordinaci způsobů vzdělávání prostř̌ednictvím Španělského svazu církevních škol sociální práce

1 Srov. María Victoria MOLINA SÁNCHEZ, Las enseñanzas del trabajo social en España, 1932-1983: estudio socio-educativo, Madrid: Universidad Pontificia de Comillas, 1994.

2 Srov. José ANDRÉS-GALLEGO, Pensamiento y acción social de la Iglesia en España, Madrid: Espasa-Calpe, 1984.

3 Jsou organizovány od roku 1906 každé dva roky a v současné době jsou pořádány Španělskou biskupskou konferencí. 
(FEEISS, Federación Española de Escuelas de la Iglesia de Servicio Social). ${ }^{4}$ Tím se katolická církev stala hybnou silou v procesu profesionalizace sociální práce ve Španělsku v té době. „Profesionalizace“ činnosti, ke které došlo v Německu s konceptem „péče“, je ve Španělsku po dlouhou dobu záležitostí církevních koncepcí sociální péče, zasazených do rudimentárního, autoritářského a korporativního modelu sociálního státu, který s demokratizací Španělska nabývá univerzálních rysů a vyvíjí se ve svébytný středomořský, katolický režim sociálního státu. ${ }^{5}$ V tomto procesu se sociální pracovníci emancipují od církevního kontextu a vzdělávání probíhá pod státní kontrolou zejména na státních univerzitách, což vede k tomu, že těžištěm ve studijních oborech se stávají témata sociální politiky a sociálního práva a nesrovnatelně menší podíl zaujímá metodika a výzkum. Nabídka státem organizovaného studia vytváří na církevní školy tlak na přizpůsobení se, což následně z různých důvodů (úbytek počtu studentů, přestárlé vedoucí struktury, chybějící zájem vedení církví, problémy s financováním atd.) vede k jejich postupnému uzavírání. Tím samozřejmě zanikají i rámcové podmínky teologického studia, jako např. zapojení církve do institucionálního vzdělávání u diecézních škol do roku 1983. Přesto by však teoreticky mohly pro vzdělávání sociálních pracovníků existovat styčné body s teologií i na státních univerzitách v etických, antropologických a kulturních sociálních situacích, v nichž může být jednání sociálních pracovníků svébytným příspěvkem. Jde zde především také o otázku hodnot v sociální práci a o referenční modely pro odbornou praxi, jakož i o kritické vyrovnávání se s obrazem člověka, který odráží sociální politiku. ${ }^{6}$

\section{Nabídky studia sociální práce ve Španělsku}

Španělsko mělo v akademickém roce 2015/2016 celkem 84 univerzit, $\mathrm{z}$ toho 50 státních $(1,81$ univerzit na milion obyvatel) s celkem 343 studijními místy (campus) a 1529730 imatrikulovanými studenty (31,1 \% mladých mezi 18 a 24 lety věku studuje). ${ }^{7}$ Celkově jsou studijní obory Sociální práce a Sociální pedagogika v roce 2016/2017 nabízeny na 33 státních a 6 soukromých univerzitách. ${ }^{8} \mathrm{Na}$ státních univerzitách je nabízeno 4036 studijních míst pro první rok studia a v akademickém roce 2016/2017 se imatrikulovalo 3765 nových studentů. Celkem studovalo v akademickém roce 2015/2016 21680 studentů Sociální práci na státních univerzitách, z toho bylo 17718 žen. Na soukromých univerzitách naproti tomu studovalo v roce 2015/2016 pouze 802 studentů (637 žen a 165 mužů), tzn. pouze kolem 3,7 \% všech studentů volí soukromou uni-

4 Srov. María Victoria MOLINA SÁNCHEZ, Las enseñanzas del trabajo social en España..., s. 65-67.

5 Srov. Stefan LESSENICH, Wohlfahrtsstaat, Arbeitsmarkt und Sozialpolitik in Spanien. Eine exemplarische Analyse postautoritären Wandels, Opladen: Leske und Budrich, 1995; Luis MORENO FERNÁNDEZ - Sebastian SARASA URDIOLA, Génesis y desarrollo del Estado de bienestar en España, Revista Internacional de Sociología 6/1993, s. 27-69; Gregorio RODRÍGUEZ CABRERO, The Consolidation of the Spanish Welfare State (1975-2010), In Anna Marta GUILLÉN - Margarita LEÓN (Eds.), The Spanish Welfare State in European Context, Farnham: Ashgate, 2011.

6 Srov. Antonio GUTIERREZ RESA (Ed.), Orígenes y desarrollo del Trabajo Social, Madrid: Ediciones Académicas, 2010, s. 301nn; Francisco IDARETA GOLDARACENA - María Jesús ÚRIZ PEMÁN - Juan Jesús VISCARRET GARRO, 150 años de historia de la ética del Trabajo Social en España: periodización de sus valores éticos, Cuadernos de Trabajo Social, 2017, 30/1, s. 37-50.

7 Zdroj: MINISTERIO DE EDUCACIÓN, CULTURA Y DEPORTE, Datos y cifras del sistema universitario español Curso 2015-2016, Madrid: Publicaciones del Ministerio, 2016, s. 3. Sociální práce a sociální pedagogika jsou ve statistice ministerstva vedeny pod zdravotními a nikoli pod sociálními vědami. Na univerzitách jsou studijní programy vyučovány bud’ v kontextu sociálních nebo humanitních věd, nebo dokonce na samostatných fakultách (např. na státní univerzitě v Granadě, na univerzitě Complutense v Madridu a v Murcii). Model začlenění sociální práce do teologických fakult, jako je tomu v Německu, Rakousku, Polsku, na Slovensku nebo v České republice s katedrami charitativní práce, není v současné době ve Španělsku možný, nebot tyto nejsou oprávněny vydávat osvědčení o státní závěrečné zkoušce.

8 Zdroj: S. G. DE COORDINACIÓN Y SEGUIMIENTO UNIVERSITARIO, Sistema Integrado de Información Universitaria (SIIU), Ministerio de Educación, Cultura y Deporte, 2017. 
verzitu, ${ }^{9}$ většinou se přitom jedná o katolické univerzity. Tím je počet potenciálních př́ijemců teologické nabídky v rámci studijního oboru Sociální práce relativně malý. Tento studijní obor nabízejí katolické univerzity ve Valencii, jezuité v Comillas (Madrid) a Deustu (Bilbao a San Sebastiano). Další katolicky inspirovaná centra jsou univerzity Ramón Llull (Barcelona), La Salle v Madridu (začleněná do Autonomní univerzity v Madridu) a Diecézní škola v Leónu (začleněná do Univerzity v Leónu). Studijní obor je nabízen většinou ve spojení s oborem Sociální pedagogika s možností získání tzv. double-degree.

Podle údajů SIUU je u katolických univerzit a katolicky inspirovaných center s nabídkou studia Sociální práce následující situace:

Tabulka 1: Imatrikulovaní studenti v oboru Sociální práce na katolických univerzitách (přednáškový cyklus 2015/2016)

\begin{tabular}{|llll|}
\hline Univerzita & Imatrikulovaní studenti & Muži & Ženy \\
Katolická univerzita ve Valencii & $-\ldots-$ & $-\ldots$ & - - - \\
Ramón Llull (Barcelona) & 165 & 24 & 141 \\
$\begin{array}{l}\text { Jezuitská univerzita: Deusto (Bilbao a San } \\
\text { Sebastián) }\end{array}$ & 331 & 86 & 245 \\
$\begin{array}{l}\text { Jezuitská univerzita: Comillas (Madrid) } \\
\begin{array}{l}\text { La Salle začleněná do Autonomní univerzity } \\
\text { v Madridu (Madrid) }\end{array}\end{array}$ & 68 & 10 & 58 \\
$\begin{array}{l}\text { Diecézní škola začleněná do Univerzity León } \\
\text { (León) }\end{array}$ & 46 & 16 & 60 \\
\hline
\end{tabular}

Zdroj: Tabulka vytvořena podle dat SIUU. U Katolické univerzity ve Valencii chybí data

\section{Integrace teologických obsahů do studijních plánů}

Na základě analýzy studijních plánů a daných informací o přednáškách na webových stránkách vzdělávacích center se v prvním kroku pokusíme podat obecný přehled o obsazích a rámcových tématech, u nichž se vyskytují styčné body s teologickými obsahy v nejširším slova smyslu. Dalším kritériem pro zkoumání místa teologie ve studijních plánech je její zařazení coby povinného či volitelného předmětu do studijních plánů a velikost předmětu co do hodinové dotace. Analýzu integrace teologie souhrnně uvádí následující tabulka.

Tabulka 2: Integrace náboženských a teologických obsahů do studijních plánů Sociální práce na katolických univerzitách (přednáškový cyklus 2016/2017)

\begin{tabular}{|lll|}
\hline Univerzita & $\begin{array}{l}\text { Nabídka předmětů / kreditní } \\
\text { systém ECTS }\end{array}$ & Volitelný / povinný \\
\hline $\begin{array}{l}\text { Katolická univerzita ve } \\
\text { Valencii }\end{array}$ & $\begin{array}{l}\text { Antropologie (18): z toho Sociální } \\
\text { učení církve (6) }\end{array}$ & Povinný \\
Ramón Llull (Barcelona) & $\begin{array}{l}\text { Náboženský dialog a Sociální akce } \\
\text { (3) z 23 nabízených. }\end{array}$ & Volitelný \\
& $\begin{array}{l}\text { Sociální antropologie (6): podtéma } \\
\text { Spiritualita }\end{array}$ & Povinný \\
\hline
\end{tabular}

9 Zdroj: webová stránka S. G. de Coordinación y Seguimiento Universitario s daty za období 2015-2016, dostupné na: http:// www.educacion.gob.es/educabase/tabla.do?path=/Universitaria/Indicadores/2017/2_Academico/1_Grado/10/\&file=EIU02101. px\&type $=$ pcaxis $\& \mathrm{~L}=0 \% 3 \mathrm{C} /$ font $\% 3 \mathrm{E}$ 


\begin{tabular}{|lll|}
\begin{tabular}{|l} 
Jezuitská univerzita: Deusto \\
(Bilbao a San Sebastián)
\end{tabular} & $\begin{array}{l}\text { Bible a kultura (6) } \\
\text { Východ a Západ ve svých velkých } \\
\text { náboženských tradicích (6) } \\
\text { Sociální participace a hodnoty (6) } \\
\text { Kritické opce sociálního života (6) }\end{array}$ & $\begin{array}{l}\text { Jeden z 9 nabízených } \\
\text { musí být zvolen jako } \\
\text { volitelný }\end{array}$ \\
$\begin{array}{l}\text { Jezuitská univerzita: Comillas } \\
\text { (Madrid) }\end{array}$ & $\begin{array}{l}\text { Křestanství a sociální etika (6) } \\
\text { La Salle (Madrid) }\end{array}$ & $\begin{array}{l}\text { Povinný } \\
\text { a občanství (6) }\end{array}$ \\
$\begin{array}{l}\text { Diecézní škola začleněná do } \\
\text { Univerzity León (León) }\end{array}$ & $\begin{array}{l}\text { Interkulturalita, náboženství } \\
\text { a způsoby pohledu na realitu (6) - } \\
\text { sociologie náboženství. }\end{array}$ & Volitelný \\
\hline
\end{tabular}

Zdroj: Tabulka vytvořena na základě Studijního průvodce zveřejňovaném na webových stránkách univerzit

Na základě tohoto přehledu lze konstatovat, že i přes nabídku studijních možností obou jezuitských univerzit nelze stanovit jednotnou linii v tom smyslu, že sociální učení církve je nejrozšírenější a ostatní teologické obsahy spadají do kontextu náboženských teorií a spirituality. Četnost nabídek v oboru Antropologie poukazuje na styčný bod s teologickými obsahy. Pro varianty volitelných předmětů či povinných přednášek nelze stanovit žádná jasná kritéria. Překvapující je, že na Diecézní škole spočívá teologické těžiště v Sociologii náboženství nabízené jako volitelný předmět.

Martin Lechner popisuje ve svém úvodu k analýze teologie v sociální práci ${ }^{10}$ situaci v Německu, která v řadě aspektů vykazuje paralely se španělskou situací v roce 2017. Je mimořádně obtížné stanovit současného teologického zástupce ve studijních nabídkách pro Sociální práci / Sociální pedagogiku; nabídky předmětů jsou součástí široké, většinou jen volitelné nabídky, která zahrnuje různá sociální, kulturní, filosofická, etická a teologická témata; stě̌zí lze nalézt systematicky reflektovanou „Teologii pro Sociální práci“. Tento výsledek vede celkově k závěru, že teologie v těchto studijních programech, a to i na katolických univerzitách, je př́tomna marginálně.

\section{Situace a zkušenosti integrace teologie na UCAM}

Identita Katolické univerzity San Antonio v Murcii (UCAM) se odvijí od čtyř důležitých prvků: výuky, výzkumu, sportu a evangelizace - spolu se základní orientací na nabídku studijních možností zaměřenou na studenty (tutor) a na kvalitu (menší skupiny). Jako katolická univerzita, zř́zzená laiky v roce 1997 se souhlasem biskupa (Ex Corde Ecclesiae, čl. $3 \$ 3,1990$ ), měla UCAM v posledním akademickém roce 2016/2017 cca 15000 studentů. Na UCAM je na základě katolické identity všem studentům $\mathrm{v}$ bakalářském studijním programu nabídnuto, zpravidla jako modul integrované výchovy, v prvních třech letech studia šest povinných přednášek, které jsou organizovány Katedrou humanitních a náboženských věd podle jednotného studijního plánu. Zde je třeba poznamenat, že ve Španělsku je většina bakalářských studijních programů koncipována jako čtyřleté studium. Výjimku tvoří zvláštní obory, jako je zdravotnictví (medicína, farmacie, podologie, odontologie) a inženýrství, které mají zpravidla formu pětiletého studijního programu. V magisterských studijních programech, které jsou pouze jednoleté, nedochází k žádné integraci prvků teologie. Existují pouze tři magisterské studijní obory, které mají specifičtější křestanský profil:

10 Srov. Martin LECHNER, Theologie in der Sozialen Arbeit. Begründung und Konzeption einer Theologie an Fachhochschulen für Soziale Arbeit, München: Don Bosco Verlag, 2000, s. 27. 
magistr v oboru Bioetika, v oboru Křest’anská filosofie a v oboru Sociální rozvoj. Celkově je v bakalářských studijních programech rozděleno 18 ECTS na následujících šest přednášek v prvních třech letech: Teologie 1, Teologie 2 a Sociální nauka církve (vždy 3 ECTS, celkem tedy 9 ECTS), Etika a Speciální etika (6 ECTS) a Humanitní vědy (3 ECTS). Metodika počítá pro všechny tyto předměty $\mathrm{s}$ tradičními přednáškami ( 2 hodiny týdně $\mathrm{v}$ semestru), jedním seminářem $\mathrm{z}$ nabídky náboženských věd (celkem 6 hodin za semestr), domácími úkoly a písemnými zkouškami. Přednášky $\mathrm{z}$ teologie jsou výrazně orientovány na obsah a obsahy učiva $\mathrm{v}$ oboru teologie jsou většinou redukovány na důležité katechismové obsahy víry. Každý docent má však volný prostor pro přizpůsobení stylu přednášek posluchačům a různým oborům a pro zařazení atraktivních kulturních, sociálních nebo společenských aktivit do seminářu. V ostatních přednáškách jsou zprostředkovány z části církevní obsahy týkající se bioetiky, v sociálním učení církve jsou představeny principy a dokumenty. $\mathrm{V}$ humanitních vědách jde o všeobecný úvod do dějin různých kultur a kulturních projevů.

Dosud nebyly na univerzitě prováděny žádné specifické kontroly kvality těchto přednášek, ani nebylo vlastní katedrou analyzováno, jakých výsledků bylo u studentek a studentů dosaženo, s výjimkou známek, které jsou zpravidla velmi dobré, a zkoušek, u kterých téměř všichni studenti uspějí. Vysoký počet kněží v učitelském sboru (10 kněží a 12 laiků, v oboru Teologie pouze 2 teologové - laici) a úzké propojení s univerzitní pastorací má nabízet evangelizující podněty ve výuce, zejména má probíhat katecheze zaměřená na svátost biřmování, kterou řada studentů nepřijala, dále slavení liturgie, dny ztišení a meditace či poutě (Caravaca, Lourdy, Fatima, Světové dny mládeže). Vyučující procházejí stejně jako všichni profesoři v každém semestru studentským hodnocením podle všeobecných univerzitních měřítek (plánování výuky, program, evaluace atd.). Srovnání vyučujících Teologie a ostatních oborů dosud neexistuje. Souhrnně lze říci, že UCAM dává dotací 18 ECTS ve třech letech a přiřazením Teologie a Etiky k povinným předmětům tomuto oboru vysokou důležitost. Většina studentů však chápe tuto strategii povinných přednášek spíše jako vynucování účasti, na níž nakonec závisí možnost získání univerzitního diplomu. Je zde snaha o zapojení do univerzitní pastorace, neprobíhá však téměř žádné kooperativní plánování a nabídky jsou koordinovány univerzitním kaplanem s vedoucím katedry. Lze konstatovat, že ochota profesorů zapojit se do těchto aktivit je omezená, zejména tam, kde se jedná o laiky, kteří sledují i akademickou kariéru (akreditace). Kněží jsou ochotni spolupracovat v určitých situacích a předsedat například dennímu slavení Eucharistie. Protože však vykonávají práce v rámci místních farností a vyučují v kněžském semináři, jsou pro UCAM k dispozici jen v omezené míre.

\section{Teologie a Sociální rozvoj v magisterském studijním programu}

\subsection{Studijní plán}

Magisterský studijní program Sociální rozvoj je adaptací freiburgského studijního oboru Teorie charity na španělskou situaci na univerzitách s dvouletým studijním plánem koncipovaným jako kombinované studium, které se skládá ze 4 modulů s 11 studijními bloky a celkem 90 ECTS: 
Tabulka 3. Studijní plán magisterského studijního programu Sociální rozvoj, UCAM (plán 2013)

\begin{tabular}{|c|c|c|c|}
\hline $\begin{array}{l}\text { Modul 1: Teoretický } \\
\text { základ oboru Sociální } \\
\text { rozvoj }\end{array}$ & $\begin{array}{l}\text { Modul 2: Profesio- } \\
\text { nální vzdělávání pro } \\
\text { obor Sociální rozvoj }\end{array}$ & $\begin{array}{l}\text { Modul } 3 \\
\text { Praxe }\end{array}$ & $\begin{array}{l}\text { Modul } 4 \\
\text { Závěrečná } \\
\text { magisterská práce }\end{array}$ \\
\hline $\begin{array}{l}\text { 1. Sociální rozvoj } \\
\text { a služby dobrovolníků } \\
\text { ( } 8 \text { ECTS) } \\
\text { 2. Sociální učení círk- } \\
\text { ve a teologie charity } \\
\text { ( } 5 \text { ECTS) } \\
\text { 3. Rozvoj a sociální } \\
\text { pomoc (10 ECTS) }\end{array}$ & $\begin{array}{l}\text { 1. Komunikační kom- } \\
\text { petence pro pomáha- } \\
\text { jící vztah ( } 5 \text { ECTS) } \\
\text { 2. Zdravotnická peda- } \\
\text { gogika jako sociální } \\
\text { intervence (6 ECTS) } \\
\text { 3. Výzkumné metody } \\
\text { (10 ECTS) }\end{array}$ & \multirow[t]{2}{*}{ Praxe (10 ECTS) } & \multirow[t]{2}{*}{$\begin{array}{l}\text { Závěrečná } \\
\text { magisterská práce (15 } \\
\text { ECTS) }\end{array}$} \\
\hline $\begin{array}{l}\text { 4. Globalizace a roz- } \\
\text { vojová kooperace ( } 6 \\
\text { ECTS) }\end{array}$ & $\begin{array}{l}\text { 4. Projektové } \\
\text { plánování a man- } \\
\text { agement kvality (6 } \\
\text { ECTS) } \\
\text { 5. Sociální } \\
\text { pedagogika a rozvoj } \\
\text { (9 ECTS) }\end{array}$ & & \\
\hline 29 ECTS & 36 ECTS & 10 ECTS & 15 ECTS \\
\hline $1-1$ a $2-2$ & $1-2$ a $2-1$ & $2-2$ & $2-2$ \\
\hline
\end{tabular}

Zahájení studia je možné každoročně k měsíci říjnu. V akademickém roce 2017/2018 je nabízeno 12. vydání akreditovaného studijního plánu. Studenti jsou z více než $80 \%$ zaměstnaní a přicházejí z různých studijních oborů (Sociální vědy, Pedagogika, Zdravotní vědy, Teologie atd.); část studentů je z Latinské Ameriky. Počet studentů kolísá mezi 15 a 35 studenty za rok u nových studentů, celkový počet studentů je 50-60 v obou cyklech. Kolem $70 \%$ studentů jsou ženy, což přibližně odpovídá výraznému počtu žen v sociální oblasti. Následující tabulka ukazuje různé věkové struktury studijního oboru s výrazným počtem starších studentů, kteří po několika letech práce hledají komplementární doplňující vzdělání nebo potřebují magisterský titul pro svou profesní dráhu ve veřejných službách: 
Graf 1: Věkové skupiny studentů magisterského studijního programu v letech 2010-2016

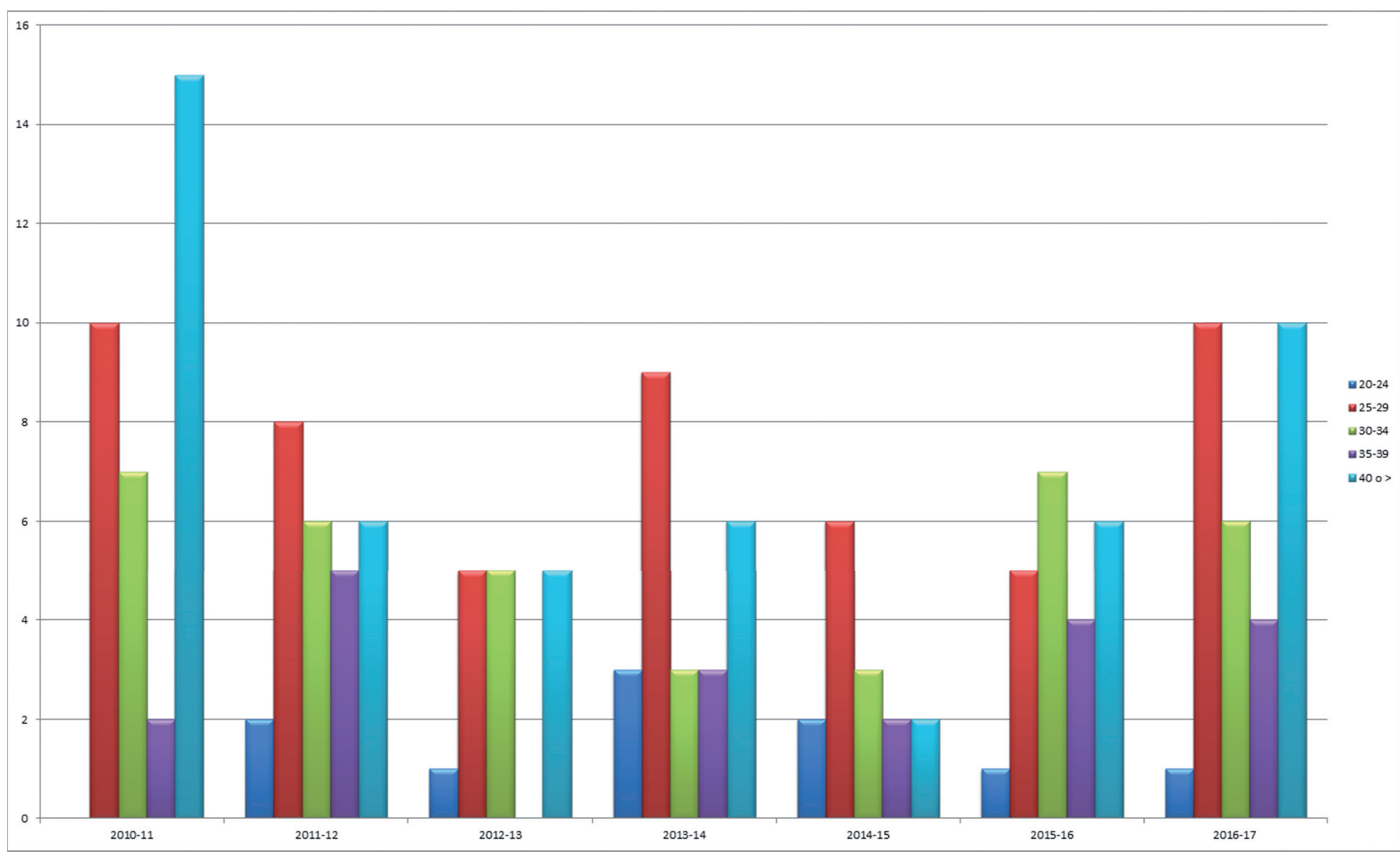

\subsection{Integrace teologie do konceptu Sociálního rozvoje}

Společenské změny, sociální rozvoj, sociální soudržnost a posilování autonomie a sebeurčení člověka jsou cíle, které chce sociální práce podporovat. ${ }^{11}$ Tím se návrhy na vytvoření teologického základu sociálního rozvoje dostávají do napětí s různými diskursy týkajícími se rozvoje a politik, které z perspektivy sociální práce obsahují určitý autonomní obraz člověka, který pomocí vlastních teorií sociální práce a hodnot sociální spravedlnosti, lidských práv, společné odpovědnosti, úcty $\mathrm{k}$ rozmanitosti, jakož i interdisciplinárně a s indigenním věděním podněcuje lidi a struktury k tomu, aby zvládali a zlepšovali výzvy života. V definicích sociální práce se tudíž nacházejí hodnoty a soteriologické postuláty, které veskrze korelují s teologickými koncepty, ale mohou se docela dobře obejít i bez nich. Pro pokus integrovat teologii do konceptu Sociálního rozvoje byly na UCAM nápomocné následující úvahy.

Od roku 1967 zde díky encyklice Populorum progressio (Pavel VI.) a dalším dokumentům v této linii tradice sociálního učení církve (Sollicitudo rei socialis, 1987; Caritas in veritate, 2009; Laudato si', 2015) existuje reflektující horizont, který krystalizuje v pojmu „integrálního lidského rozvoje“, a sociální učení církve tak poskytuje základní kámen k pochopení konceptu rozvoje. Nejde přitom až tolik o teologický pojem, nýbrž, vyjádřeno s Herbertem Blumerem, o „sensitizing

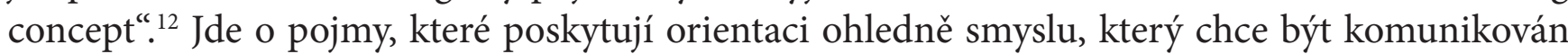
a může naznačit směr výzkumu, jako je podle Blumera např. pojem kultura, instituce, sociální struktury, zvyklosti nebo osobnost. Tato omezená funkce a dosah má svůj základ ve vlastnostech sociálního světa, každodenní zkušenosti, v níž je každý objekt jediný, odlišný a partikulární. Teologie používá rovněž „senzibilizující koncepty“, jako např. integrální lidský rozvoj, které umožňují

11 Globální definice IFSW, 2014.

12 Herbert BLUMER, „What is wrong with social theory?”, American Sociological Review 1954/19(1), s. 7. 
dialog mezi transcendentními horizonty smyslu z náboženské oblasti a sekulárními koncepty. Můžeme zde hovořit o dvojí funkci senzibilizace:

a) Jedná se o evangelizační funkci, která pomocí těchto konceptů komunikuje z teologického pohledu celostní křestanský obraz člověka a stvoření, zejména vztah k transcendentnu.

b) Jedná se rovněž o funkci mostu k jiným disciplínám, jako jsou hospodářství, sociální vědy, filosofie, sociologie atd., pomocí níž může teologie uchopit aktuální problémy a pokusit se integrovat je do svého teologického pohledu na člověka, dějiny a svět. Koncepty mostů umožňují způsob komunikace, který je v náboženském jazykovém světě obvykle vzdálený od sekulárních oblastí ekonomie, diskursů ohledně rozvoje a jeho politických obsahů.

Senzibilizující koncepty jako křestanský humanismus, integrální ekologie, integrální lidský rozvoj jsou „branami“ $k$ diskursivním realitám a spojením s uznávanými sekulárními oblastmi, jako jsou Spojené národy, vlády, hnutí, NGOs a společnost vůbec. ${ }^{13}$

\subsection{Integrace Teologie do kurikula magisterského studijního programu}

V magisterském studijním programu jsou teologické obsahy zařazeny do prvního roku studia v modulu 1 a v modulu 2. Konkrétní podoba se odvijí od teoretických základů konceptu „Sociálního rozvoje“ z perspektivy teologických disciplín, jako je Sociální učení církve (SUC) a Teologie charity $(\mathrm{TCH})$ ve výukovém programu 1 (1. semestr), jako tematického celku směřujícího ke konceptu „integrálního lidského rozvoje“ ve výukovém programu 2 (1. semestr) se 2 přednáškami a 2,5 ECTS. Je-li v oboru SUC nabízen všeobecný úvod k sociálním principům a k dějinám SUC se širokou vazbou k tématu „Sociální rozvoj“ z perspektivy SUC, doplňuje přenáška Teologie charity teologické základy křestanského jednání vzhledem k napětí mezi náboženstvím a rozvojem. Jsou zde probírány príćciny existujících deficitů integrace náboženských obsahů a praktik do stávajících politických a ideologických konceptů rozvoje, praktik a výzkumu v oblasti sociálních věd. Poté jsou na centrálních konceptech jako spravedlnost, chudoba a bohatství, inkluze a exkluze, solidarita představeny potenciály náboženství z biblické, charitativně-filosofické a mezináboženské perspektivy.

Ve výukovém programu 4 (5 ECTS, 2. semestr) „Techniky a komunikační kompetence pomáhajícího vztahu“ jsou reflektovány křestanské tradice pomoci (Ježíšovo uzdravující jednání) korelující se základními psychologickými postoji humanistické psychologie a jejich užitečnost pro praxi. V praxi (3. semestr, 10 ECTS) je studentům nabídnuta možnost seznámit se s rozvojovými projekty a křestanskými organizacemi. Závěrečná magisterská práce (4. semestr, 15 ECTS) má rovněž integrovat získané poznatky konceptu sociálního rozvoje.

Stávajícím problémem např. zůstává, jak zajistit př́tomnost hlavních teologických myšlenek, které by se jako červená nit prolínaly i dalšími nabídkami studijních možností. Studenti nastupující ke studiu $\mathrm{z}$ jiných univerzit nejsou z odborných teologických oborů, nýbrž přicházejí ze zcela rozdílných profesních a zkušenostních kontextů bez předchozího teologického vzdělání, takže je nezbytná didaktika vztažená ke zkušenosti, nikoli didaktika indoktrinační. Studenti z UCAM si přinášejí předchozí vědomosti, které mohou být v magisterském studijním programu prohloubeny a na něž se lze zaměřit. Obecně je zájem o teologickou a praktickou část velmi pozitivní, ačkoli zpočátku existují i „předsudky“.

13 Srov. Rainer GEHRIG, El desarrollo humano integral: puente entre lo sagrado y lo profano. Př́spěvek na symposiu „Desarrollo Humano Integral: una aportación del Pensamiento Social Cristiano al servicio de la justicia global”. En el 50 aniversario de la Populorum Progressio (1967-2017). Bilbao, Juni 2017. http://www.researchgate.net/publication/318260400_El_desarrollo_humano_integral_puente_entre_ lo_sagrado_y_lo_profano 
Celkově lze k situaci ve Španělsku konstatovat, že je zapotřebí dalš́ho výzkumu, aby bylo možné věnovat se těmto otázkám a vést dialog $s$ různými vzdělávacími zařízeními, což by napomohlo participovat na zkušenostech jiných zemí a být efektivním způsobem př́tomný s církví a teologií v tak důležité oblasti, jakou je vzdělávání sociálních pedagogů a sociálních pracovníků. To by španělské teologii a církvi umožnilo výraznější spojení s palčivými sociálními otázkami a španělské Caritas následně usnadnilo integraci profesionálních pracovníků do křestansko-církevní identity organizace.

Překlad: Mgr. et Mgr. Jana Maryšková

\section{Kontakt}

Assoc. Prof. Rainer Gehrig, PhD.

Universidad Católica San Antonio de Murcia (Spanien)

Department für Religions- und Humanwissenschaften

Internationales Institut für Caritas und Freiwilligendienste Johannes Paul II.

Campus de los Jerónimos s/n, E-30107 Guadalupe-Murcia

gehrig@ucam.edu 